\title{
MANAGEMENT OF THE ROOT-KNOT NEMATODE MELOIDOGYNE INCOGNITA ON TOMATO WITH DIFFERENT COMBINATIONS OF NEMATICIDES AND A RESISTANT ROOTSTOCK: PRELIMINARY DATA
}

\author{
(*) Consiglio per la ricerca in agricoltura e l'analisi dell'economia agraria - Research Centre for Plant Protection and \\ Certification (CREA-DC), via Lanciola 12/A, 50125, Firenze, Italy. \\ (**) University of Naples "Federico II", Department of Agricultural Sciences, via Università 100, 80055 Portici, Naples, \\ Italy. \\ Corresponding author: giada.derrico@unina.it
}

Landi S., d'Errico G., Roversi P.F., d'Errico F.P. - Management of the root-knot nematode Meloidogyne incognita on tomato with different combinations of nematicides and a resistant rootstock: preliminary data.

In south Italy, tomato growers commonly face severe root-knot nematode infestations. Alternative methods of control are required because of the high toxicity of current pesticides. Therefore, the potential of an integrated pest management strategy for the control of root-knot nematodes on tomato in greenhouse was investigated. The nematode susceptible tomato cv. Ikram, non-grafted or grafted onto the tomato rootstock cv. Armstrong, with intermediate resistance to the nematode, in combination with soil applications of the nematicides fosthiazate, oxamyl, and abamectin were tested. The resistant rootstock significantly reduced nematode soil population levels and root galling index until one month after transplanting, when soil temperature was below $28^{\circ} \mathrm{C}$, but not by harvest due to increased soil temperature. Fosthiazate, abamectin and oxamyl increased tomato yield and reduced root galling caused by Meloidogyne incognita. The synergistic effect of the rootstock resistant to root-knot nematodes and soil treatments of fosthiazate in combination with abamectin or oxamyl could successfully be employed in integrated pest management programs to control M. incognita in tomato.

KeY WoRDS: $M i-1$ resistance gene; fosthiazate; abamectin; oxamyl

\section{INTRODUCTION}

Root-knot nematodes (Meloidogyne spp.) are among the most damaging agricultural pests attacking a wide range of crops (SAHEBANI \& HADAVI, 2008; D’ERRICO et al., 2014). Yield losses of $20.6 \%$ have been reported in tomato (RAVICHANDRA, 2014), although, this value could be underestimated because of the known negative synergistic interaction between fungi and nematodes (MANZANILLA \& StARr, 2009; RAgOZZINo \& D’ERrico, 2011). Damages caused to tomato, mainly by Meloidogyne incognita (Kofoid \& White) Chitw., are particularly severe in southern Italy (D'ERRICO et al., 2016). Therefore, the application of fumigant and non-fumigant nematicides is instrumental for satisfactory productions (NYCZEPIR \& THOMAS, 2009). The withdrawal from market or restrictions in the use of several soil fumigants such as methyl bromide,chloropicrin, and 1,3-dichloropropene (1,3-D), able to reduce the soil population densities of the nematode to levels that could be tolerated by the following two crop cycles, have prompted researches on integrated control strategies suitable to the crop and the environmental sustainability (NYCZEPIR \& THOMAs, 2009).

Among the various measurements for controlling rootknot nematodes on tomato, plant resistance is considered an effective, economic and environment friendly method. The Mi-1 gene, identified in Solanum peruvianum L. and introgressed in many tomato cultivars, confers high level of resistance to $M$. incognita, $M$. javanica and $M$. arenaria (JACQUET et al., 2005), which are the most common species occurring all over the world, including southern Italy were they are often present as mixed populations. The same Mi-1 gene governs the root-knot nematode resistance in several rootstocks used for grafting tomato. Unfortunately, both resistant cultivars and rootstocks may select for virulent populations of the nematode if used routinely (JARQUINBARBERENA et al., 1991; KALOSHIAN et al., 1996; VERDEJOLUCAs et al., 2009). However, new resistant rootstocks derived from crosses between different wild Solanum species are being tested (CORTADA et al., 2008; 2009). The degree of resistance of the new rootstocks varies from high to intermediate, but some of them confer resistance also to virulent populations of these nematodes (WILLIAMSON \& ROBERTS, 2009). To preserve the durability of the resistance and prevent the selection of virulent populations of these nematodes, resistant cultivars and rootstocks are suggested to be used within an Integrated Pest Management (IPM) context (VERDEJO-LUCAS \& SORRIBAS, 2008).

Therefore, the objective of this investigation was to evaluate the potential of an IPM strategy for the control of rootknot nematodes in tomato in greenhouse. To achieve this goal, combinations of a resistant tomato rootstock and soil applications of the nematicides fosthiazate, oxamyl, and abamectin were tested.

\section{MATERIALS AND METHODS}

\section{PlanT AND CHEMICALS}

Tomato plants, Solanum lycopersicum L., cv. Ikram susceptible to Meloidogyne spp., grafted or non-grafted onto the resistant tomato rootstock cv. Armstrong were planted. Both cultivars were supplied by Syngenta. The nematicides tested were Fosthiazate $150 \mathrm{~g} \mathrm{~L}^{-1}$ (Nemathorin $150 \mathrm{EC}$, Syngenta), Oxamyl $100 \mathrm{~g} \mathrm{~L}^{-1}$ (Vydate 10L, DuPont) and Abamectin $20 \mathrm{~g} \mathrm{~L}^{-1}$ (Tervigo SC 1, Syngenta). 
FIELD SITE

The tomato trial was conducted in two contiguous commercial unheated plastic-houses, each of $630 \mathrm{~m}^{2}(10 \times 63$ $\mathrm{m})$, in the Nocera-Sarno area, southern Italy. The trial was established during summer of 2013. The plastic-houses had been under conventional tomato production for 30 years before the start of the experiment. The soil at the experimental site was sandy-loamy, with soil $\mathrm{pH}$ of 7.8, and uniformly and severely infested with $M$. incognita, as it was shown by the severe root galling and damage to lettuce cropped just before arranging the experiment. The mean temperatures in a nearby greenhouse in June, July, August and September were $26.5 \pm 3.0(\mathrm{SD}), 29.7 \pm 1.8,30.8 \pm 1.6$ and $26.4 \pm 4.1$, respectively (Fig. 1).

\section{CHEMICAL TREATMENTS}

The nematicide treatments were: (a) fosthiazate, applied three days before transplanting by furrow at the dose of $10 \mathrm{~L}$ $\mathrm{ha}^{-1}$; (b) fosthiazate, applied as above three days before transplanting at the dose of $10 \mathrm{~L} \mathrm{ha}^{-1}$ followed by two applications of abamectin, each at $5 \mathrm{~L} \mathrm{ha}^{-1}, 24$ and 35 days after transplanting; (c) fosthiazate applied three days before transplanting as above at the dose of $10 \mathrm{~L} \mathrm{ha}^{-1}$ followed by two applications of oxamyl, each at $10 \mathrm{~L} \mathrm{ha}^{-1}, 24$ and 35 days after transplant; (d) four applications of abamectin, each at the dose of $5 \mathrm{~L} \mathrm{ha}^{-1}$, every 10 days from transplanting; (e) four applications of oxamyl, each at the dose of $5 \mathrm{~L} \mathrm{ha}^{-1}$, every 10 days from transplanting; (f) untreated control.

\section{LAYOUT OF THE EXPERIMENT}

The greenhouses were divided in plots of $25 \mathrm{~m}^{2}(10 \mathrm{~m} \times$ $2.5 \mathrm{~m}$ ) each and the treatments were arranged according to a randomized block design with four replicates, two in each greenhouse. An individual plot consisted of 2 rows of plants in the centre of each plot; one row planted with the susceptible cv. Ikram and the other with cv. Ikram grafted onto the resistant rootstock cv. Armstrong. There were 21 nongrafted or 21 grafted plants per individual row, spaced $50 \mathrm{~cm}$ along the row and $1 \mathrm{~m}$ between rows.

The application of the nematicides was made via drip irrigation by distributing $15.000 \mathrm{~L}$ water ha ${ }^{-1}$. Besides the normal irrigation system, two sections of drip-line, as long as the plot row, were joined and transferred from time to time in the plot to be treated. The drip-line supplied with self-compensating drippers of a flow rate of $2 \mathrm{~L} / \mathrm{hour}$, had the hind-end closed by a cap and the fore-end connected to a pump (shoulder "ECHO") to distribute the solutions into the soil at the pressure of $2 \mathrm{~atm}$. The untreated plots were irrigated by the same volume of water of the treated plots.

Six-week-old tomato seedlings were transplanted in each plot on June 22, 2013. Plants were staked and tied as needed during the season. Ordinary irrigation and fertilization were provided according to requirements of the crops. Insecticides, herbicides and fungicides were applied as recommended (MAYNARD et al., 2003).

\section{DATA COLLECTION}

Soil samples were collected three days before transplanting (immediately after ploughing) and again 30 and 83 (end of the crop cycle) days after transplanting, and $M$. incognita second-stage juveniles (J2s) were extracted and counted. Ten soil core samples were taken from each plot, giving a total of about $0.35 \mathrm{~kg}$ soil per plot. The soil cores were collected uniformly on the plots before planting and along the row after transplanting. Each soil sample was thoroughly mixed and a $100 \mathrm{~cm}^{3}$ sub-sample processed combining the Cobb's sieving and decanting method with a modified Baermann's funnel technique and the nematodes in the soil suspension counted under a stereomicroscope.

Root-knot nematode infestation was evaluated 30 and 83 days after transplanting on the base of the Root Galling Index (RGI) according to a 0-5 scale (LAMBERTI, 1971), were $0=$ no galls - healthy plant, $1=1-5$ galls per plant very slight damage, $2=6-20$ galls - moderate damage, $3=$ more than 20 galls - medium damage, $4=$ root system reduced and showing some large galls, $5=$ root system completely destroyed or showing many large galls. Ten plants per plot ( 5 from the non-grafted and 5 from the grafted row) were uprooted at each evaluation date.

Plant vigour ratings of 10 plants per plot (5 per row) were estimated according to the weight $(\mathrm{kg})$ of the whole plant fresh matter at 83 days after transplanting. Tomatoes of 10 plants per plot ( 5 per row) were harvested as they matured and total yields calculated by summing the weights of the six consecutive harvests (August 14, 21, 28 and September $3,9,13)$.

\section{STATISTIC ANALYSIS}

All data were submitted to analysis of variance (one wayANOVA) and, when the F-test was significant at $P<0.05$, treatment means were compared using the StudentNewman-Keuls test (Costat program). Factorial ANOVA was performed to test the effect of main factors (nematicide treatments, rootstock), and their interaction. If a main effect was significant, the ANOVA was followed by StudentNewman-Keuls test at $P<0.05$.

\section{RESULTS}

At the beginning of the trial, the nematode soil infestation level (Table 1) was homogeneous among the different plots: $156.2 \pm 0.20$ (SE) nematodes per $100 \mathrm{~cm}^{3}$ of soil. After transplanting, the nematode population in soil decreased 30 days after transplanting, probably because of penetration of the nematode juveniles into the roots, but greatly increased 83 days after transplanting, because of the nematode reproduction, with significant differences among the treatments (Table 1)

Thirty days after transplanting (Table 1), the nematode population increased slightly on non-grafted tomatoes and remained at the same level on grafted tomatoes, probably because only a small proportion of the nematodes were already laying eggs of the first generation on grafted tomatoes. Also, there were no significant differences in soil population densities of the nematodes among plots treated and planted with grafted tomatoes or treated and planted with non-grafted tomatoes. However, the nematode soil population densities were significantly smaller along the row in the plots planted with grafted plants.

Instead, the nematode soil population densities greatly increased 83 days after transplanting (Table 1) in plots transplanted with both grafted and non-grafted tomatoes, when the nematode had probably completed about two generations (Table 1). At this date, compared with the control, in the non-grafted tomato rows the least nematode soil populations occurred in plots receiving combined treatments of fosthiazate and avermectin or oxamyl, while fostiazate and oxamyl alone gave intermediate results. Abamectin alone did not significantly reduce soil nematode density. In rows planted with grafted tomatoes, only the combined treatments of fosthiazate with abamectin or oxamyl reduced significantly the nematode soil population level and no differences occurred in plots planted with grafted or nongrafted tomatoes (Table 1). 
Table 1 - Effects of the nematicides on second-stage juveniles of Meloidogyne incognita per $100 \mathrm{~cm}^{3}$ of soil in plots planted with nongrafted susceptible tomato cv. Ikram and grafted onto the resistant rootstock cv. Armstrong 30 and 83 days after transplanting (DAT). Each data is the average of four replicated plots. Data on the same column sharing a common letter are not significantly different $(P=$ $0.05)$ according to Student-Newman-Keuls test. * indicates statistical $(P=0.05)$ differences, between non-grafted and grafted plants according to Student-Newman-Keuls test. Average nematode population as affected by nematicide treatment (row) and grafting (column). A single representative experiment is shown.

\begin{tabular}{|c|c|c|c|c|c|c|c|}
\hline \multirow{2}{*}{ Treatment } & \multirow{2}{*}{$\begin{array}{c}\text { Before } \\
\text { planting }\end{array}$} & \multicolumn{3}{|c|}{30 DAT } & \multicolumn{3}{|c|}{83 DAT } \\
\hline & & Non-grafted & Grafted & $\begin{array}{c}\text { Average } \\
\text { per treatment }\end{array}$ & Non-grafted & Grafted & $\begin{array}{c}\text { Average } \\
\text { per treament }\end{array}$ \\
\hline Fosthiazate & $170 \mathrm{a}$ & $70.0 \mathrm{a}$ & $10.0 \mathrm{a} *$ & $40.0 \mathrm{a}$ & $4100.0 \mathrm{~b}$ & $3760.0 \mathrm{ab}$ & $3930.0 \mathrm{bc}$ \\
\hline Fosthiazate + Abamectin & $120 \mathrm{a}$ & $30.0 \mathrm{a}$ & $12.5 \mathrm{a} *$ & $21.3 \mathrm{a}$ & $2140.0 \mathrm{c}$ & $2900.0 \mathrm{~b}$ & $2520.0 \mathrm{~d}$ \\
\hline Fosthiazate + Oxamyl & $190 \mathrm{a}$ & $40.0 \mathrm{a}$ & $10.0 \mathrm{a}^{*}$ & $25.0 \mathrm{a}$ & $1990.0 \mathrm{c}$ & $2645.0 \mathrm{~b}$ & $2317.0 \mathrm{~d}$ \\
\hline Abamectin & $130 \mathrm{a}$ & $60.0 \mathrm{a}$ & $35.0 \mathrm{a}^{*}$ & $47.5 \mathrm{a}$ & $5137.5 \mathrm{ab}$ & $4580.0 \mathrm{ab}$ & $4858.8 \mathrm{~b}$ \\
\hline Oxamyl & $160 \mathrm{a}$ & $60.0 \mathrm{a}$ & $20.0 \mathrm{a}^{*}$ & $40.0 \mathrm{a}$ & $4257.5 \mathrm{~b}$ & $4050.0 \mathrm{ab}$ & $4153.8 \mathrm{c}$ \\
\hline Control & $170 \mathrm{a}$ & $95.0 \mathrm{a}$ & $30.0 \mathrm{a}^{*}$ & $62.5 \mathrm{a}$ & $6190.0 \mathrm{a}$ & $5590.0 \mathrm{a}$ & $5890.0 \mathrm{a}$ \\
\hline Average & & $59.2 \mathrm{a}$ & $19.6 \mathrm{~b}$ & & $3969.0 \mathrm{a}$ & $3920.8 \mathrm{a}$ & \\
\hline
\end{tabular}

On non-grafted plants, root gall indices (Table 2) were low 30 days after transplanting and significantly higher in the control plots (1.5) compared to all nematicide treated plots $(0.2-0.7)$ (Table 2). The RGI was largest $(P<0.05)$ in the control plots (4.7) 83 days after transplanting, and least in those treated with fosthiazate alone (2.9) or combined with abamectin (2.7). Fosthiazate alone and combined with abamectin and oxamyl were the most effective treatments in reducing RGI on grafted tomatoes. From pairwise comparisons between non-grafted susceptible plants and grafted onto the resistant rootstock, for each treatment, significant differences were found only for $\mathrm{J} 2 \mathrm{~s}$ in soil and root galling index 30 days after transplanting (Tables 1 and 2) as the grafted plants were effective in controlling M. incognita infestation.

Only treatments of fosthiazate, alone or combined with abamectin or oxamyl, increased significantly the fresh weight of non-grafted plants, while these treatments and oxamyl increased the fresh weight of grafted plants. All nematicides greatly increased cumulated tomato yield of non-grafted and grafted plants compared to the untreated plots (Table 3). The greatest yield increases of $251-261 \%$ were obtained in plots treated with fosthiazate in combination with abamectin or oxamyl and planted with non-grafted or grafted tomatoes. The other treatments gave intermediate yield increases. The averages of plant weight and yield did not significantly differ between non-grafted and grafted tomato plants (Table 3).

The factorial ANOVA showed that treatment, rootstock resistant to the nematodes and their interactions had a significant effect on root galling index but only 30 days after transplanting (Table 4). Root galling indices were lower on nematicide treated than untreated plants and on the resistant rootstock than on susceptible plants. Moreover, the resistant rootstock resulted in a significant suppressing effect on nematode J2s in the soil, while the nematicide treatments had no significant difference effect (Tables 1 and 2). In contrast, 83 days after transplanting, the factorial analysis showed that treatment effect was significant for J $2 \mathrm{~s}$ in the soil, root galling index and crop yield $(P=0.00001)$ (Table 4). Differences between non-grafted and grafted tomato plants were found only for RGI $(P=0.016)$.

Table 2 - Effects of the nematicides on root galling index of the root-knot nematode, Meloidogyne incognita, in plots planted with the susceptible tomato cv. Ikram, non-grafted and grafted on the resistant root-stock cv. Armstrong, 30 and 83 days after transplanting (DAT). Each data is the average of four replicates. Data on the same column sharing a common letter are not significantly different $(P=0.05)$ according to Student-Newman-Keuls test. * indicates statistical significant $(P=0.05)$ difference, compared with the corresponding data in the previous column, according to Student-Newman-Keuls test. In column Average per treatment and in row Average per rootstock, root galling index as affected by treatment and rootstock at 30 and 83 DAT are reported.

\begin{tabular}{|c|c|c|c|c|c|c|}
\hline \multirow[b]{2}{*}{ Treatment } & \multicolumn{3}{|c|}{30 DAT } & \multicolumn{3}{|c|}{83 DAT } \\
\hline & Non-grafted & Grafted & $\begin{array}{c}\text { Average } \\
\text { per treatment }\end{array}$ & Non-grafted & Grafted & $\begin{array}{c}\text { Average } \\
\text { per treatment }\end{array}$ \\
\hline Fosthiazate & $0.7 \mathrm{~b}$ & $0.0 \mathrm{a} *$ & $0.4 \mathrm{~b}$ & $2.9 \mathrm{c}$ & $2.3 \mathrm{c}$ & $2.6 \mathrm{c}$ \\
\hline Fosthiazate + Abamectin & $0.5 \mathrm{~b}$ & $0.0 \mathrm{a} *$ & $0.3 \mathrm{~b}$ & $2.7 \mathrm{c}$ & $2.2 \mathrm{c}$ & $2.5 \mathrm{c}$ \\
\hline Fosthiazate + Oxamyl & $0.2 \mathrm{~b}$ & $0.3 \mathrm{a} *$ & $0.3 \mathrm{~b}$ & $3.6 \mathrm{~b}$ & $2.5 \mathrm{c} *$ & $3.0 \mathrm{c}$ \\
\hline Abamectin & $0.7 \mathrm{~b}$ & $0.0 \mathrm{a} *$ & $0.4 \mathrm{~b}$ & $3.8 \mathrm{~b}$ & $3.7 \mathrm{~b}$ & $3.7 \mathrm{~b}$ \\
\hline Oxamyl & $0.7 \mathrm{~b}$ & $0.0 \mathrm{a} *$ & $0.4 \mathrm{~b}$ & $4.2 \mathrm{ab}$ & $3.9 \mathrm{~b}$ & $4.1 \mathrm{~b}$ \\
\hline Control & $1.5 \mathrm{a}$ & $0.0 \mathrm{a} *$ & $0.9 \mathrm{a}$ & $4.7 \mathrm{a}$ & $4.6 \mathrm{a}$ & $4.7 \mathrm{a}$ \\
\hline Average & $0.8 \mathrm{a}$ & $0.1 \mathrm{~b}$ & & $3.6 \mathrm{a}$ & $3.2 \mathrm{a}$ & \\
\hline
\end{tabular}


Table 3 - Effects of the nematicides on plant weight, crop yield and increase of tomato compared to the control, in plots infested with the root-knot nematode, Meloidogyne incognita, and planted with the susceptible tomato cv. Ikram, non-grafted and grafted on the resistant root-stock cv. Armstrong. Each data is the average of four replicates. Data on the same column sharing a common letter are not significantly different $(P=0.05)$ according to Student-Newman-Keuls test. * indicates statistical significant $(P=0.05)$ difference, compared with the corresponding data in the previous column, according to Student-Newman-Keuls test. In column average per treatment and in row average per rootstock, plant weight and crop yield as affected by treatment and rootstock at 30 and 83 DAT are reported.

\begin{tabular}{|c|c|c|c|c|c|c|c|c|}
\hline \multirow[b]{2}{*}{ Treatment } & \multicolumn{3}{|c|}{ Plant weight (kg/plant) } & \multicolumn{3}{|c|}{ Crop yield (kg/plant) } & \multicolumn{2}{|c|}{$\begin{array}{c}\% \text { crop yield increase } \\
\text { over control }\end{array}$} \\
\hline & Non-Grafted & Grafted & $\begin{array}{c}\text { Average } \\
\text { per } \\
\text { treatment }\end{array}$ & Non-grafted & Grafted & $\begin{array}{c}\text { Average } \\
\text { per } \\
\text { treatment }\end{array}$ & Non-grafted & Grafted \\
\hline Fosthiazate & $0.74 \mathrm{~b}$ & $0.68 \mathrm{~b}$ & $0.71 \mathrm{a}$ & $1.94 \mathrm{~b}$ & $2.08 \mathrm{~b}$ & $2.01 \mathrm{~b}$ & 128.23 & 123.65 \\
\hline Fosthiazate + Abamectin & $0.87 \mathrm{a}$ & $0.89 \mathrm{a}$ & $0.88 \mathrm{a}$ & $3.07 \mathrm{a}$ & $3.08 \mathrm{a}$ & $3.07 \mathrm{a}$ & 261.17 & 231.18 \\
\hline Fosthiazate + Oxamyl & $0.92 \mathrm{a}$ & $0.90 \mathrm{a}$ & $0.91 \mathrm{a}$ & $2.98 \mathrm{a}$ & $3.12 \mathrm{a}$ & $3.04 \mathrm{a}$ & 250.59 & 235.48 \\
\hline Abamectin & $0.55 \mathrm{c}$ & $0.53 \mathrm{c}$ & $0.54 \mathrm{a}$ & $1.35 \mathrm{c}$ & $1.34 \mathrm{c}$ & $1.35 \mathrm{~cd}$ & 58.82 & 44.08 \\
\hline Oxamyl & $0.65 \mathrm{bc}$ & $0.71 \mathrm{~b}$ & $0.68 \mathrm{a}$ & $1.63 \mathrm{bc}$ & $1.69 \mathrm{bc}$ & $1.66 \mathrm{bc}$ & 91.76 & 81.72 \\
\hline Control & $0.51 \mathrm{c}$ & $0.49 \mathrm{c}$ & $0.50 \mathrm{a}$ & $0.85 \mathrm{~d}$ & $0.93 \mathrm{~d}$ & $0.89 \mathrm{~d}$ & & \\
\hline Average & $0.71 \mathrm{a}$ & $0.70 \mathrm{a}$ & & $1.97 \mathrm{a}$ & $2.04 \mathrm{a}$ & & & \\
\hline
\end{tabular}

Table 4 - Summary of the significant effects of treatment and root-stock on root-knot nematode population, Meloidogyne incognita and root galling index at 30 and 83 days after transplanting (DAT), plant weight and crop yield and their interaction at 83 DAT. Figures in bolt indicate high significance of main effects or interaction.

\begin{tabular}{|c|c|c|c|c|c|c|}
\hline & \multicolumn{2}{|c|}{30 DAT } & \multicolumn{2}{|c|}{83 DAT } & \multirow{2}{*}{$\begin{array}{l}\text { Plant weight } \\
\text { (kg/plant) }\end{array}$} & \multirow{2}{*}{$\begin{array}{r}\text { Crop yield } \\
\text { (kg/plant) }\end{array}$} \\
\hline & $\begin{array}{c}\text { Nematodes } 100 \\
\mathrm{~cm}^{3} \text { soil }\end{array}$ & RGI & $\begin{array}{c}\text { Nematodes } 100 \\
\mathrm{~cm}^{3} \text { soil }\end{array}$ & RGI & & \\
\hline $\begin{array}{l}\text { Main effects: } \\
\text { - Treatment } \\
\text { - Rootstock }\end{array}$ & $\begin{array}{c}0.0561 \\
\mathbf{0 . 0 0 0 0 1}\end{array}$ & $\begin{array}{c}0.0002 \\
0.00001\end{array}$ & $\begin{array}{c}\mathbf{0 . 0 0 0 0 1} \\
0.4521\end{array}$ & $\begin{array}{c}0.00001 \\
0.0162\end{array}$ & $\begin{array}{c}0.0708 \\
0.09360\end{array}$ & $\begin{array}{c}\mathbf{0 . 0 0 0 0 1} \\
0.6703\end{array}$ \\
\hline $\begin{array}{l}\text { Interaction: } \\
\text { - Treatment } \\
\text { - Rootstock }\end{array}$ & 0.4436 & 0.0016 & 0.3114 & 0.4878 & 0.9990 & 0.9994 \\
\hline
\end{tabular}

\section{DISCUSSION}

Grafting susceptible cultivars onto resistant rootstock is used successfully to control soil-borne pathogens in greenhouse in many countries (CORTADA et al., 2008; 2009), including south Italy (SERGES \& COLOMBO, 2005).

In this trial, the rootstock cv. Armstrong, with intermediate resistance, reduced nematode population levels and root galling index one month after transplanting, but later no positive effect of grafting was observed. Non-grafted and grafted tomatoes exhibited similar performance in terms of plant vigor and crop yield. This result could be partially attributed to the resistance breaking because the $M i-1$ gene is not effective at soils temperatures above $28^{\circ} \mathrm{C}$ (DROPKIN, 1969; KALOSHIAN et al., 1996). In fact, the nematode densities on the resistant rootstock was low at low temperatures (June, 26.5 \pm 3.0 ) and increased with the rise of the temperature (July, 29.7 \pm 1.8 ; August, 30.8 \pm 1.6 ) (Fig. 1). Moreover, the repeated plantings of resistant tomatoes that may have occurred in past years may have selected resistancebreaking specimens of the nematode (VERDEJO-LUCAS et al., 2009). In this case, using a resistant cultivar instead of a rootstock or vice versa may not be helpful because the resistance to root-knot nematodes present in the commercial varieties of tomato is conferred by the same $\mathrm{Mi}-1$ gene. The solution of this problem necessitates the incorporation of other resistance genes into cultivated tomato and the use in the rotation of resistant tomato with other crops for extending the durability of the effectiveness of the $\mathrm{Mi}-1$ gene (KALOSHIAN et al., 1996). In this trial the resistance breaking may have been due to the high temperatures in July and August and because resistant tomato cultivars may have been included in the rotation in the cropping history of the farm. So far, chemical control measures are still needed to limit yield losses in tomato. In our study, soils treatment with fosthiazate, abamectin and oxamyl increased tomato yield and reduced root galling caused by M. incognita. Similar control results were obtained by other authors (GARABEdian \& VAN GUNDY, 1983; Pullen \& Fortnum, 1999; Gugino et al., 2006; SAAD et al., 2011; QIAO et al., 2012; D'ERRICO et al., 2017). When these chemicals were used alone, their efficacy was lower than in combination. As suggested by OKA et al. (2012), nematicides taken up by roots prevent nematode attacks only in the early growth stage of tomato and, therefore, their use is effective only to suppress root-knot nematodes in short season crop. However, when fosthiazate was applied before transplanting and followed by post-plant applications of abamectin or oxamyl, plants were protected from nematode infestation much longer than with the pre-plant application. In addition, crop plants may have also benefited of the effect of abamectin and oxamyl against insect pests (PUTTER et al., 1981). The results of this study suggest that the synergistic effect of rootstock resistant to root-knot nematodes and soil 
Fig. 1 - Average (M), minimum and maximum temperatures recorded in a greenhouse nearby those used for the experiment, from June to September 2013.

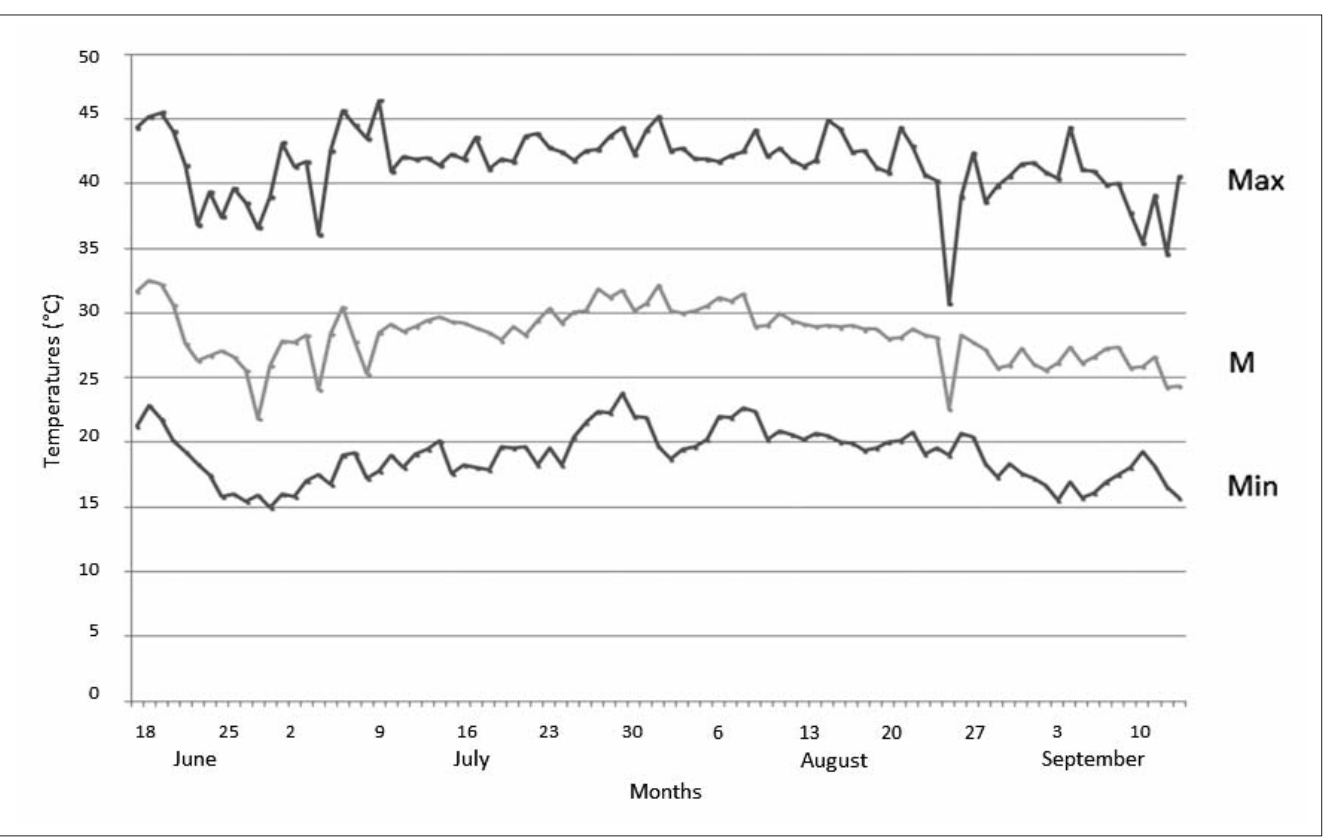

treatments with fosthiazate in combination with abamectin or oxamyl could successfully be employed in integrated pest management (IPM) programs to control $M$. incognita in tomato.

\section{ACKNOWLEDGEMENTS}

We would like to thank Dr. Ciro Cosimo Santoro and Dr. Claudio Malagrinò from Syngenta for providing materials.

\section{REFERENCES}

Cortada L., Sorribas F.J., Ornat C., Kaloshian I., VERDEJO-LuCAS S., 2008 - Variability in infection and reproduction of Meloidogyne javanica on tomato rootstocks with the Mi resistance gene. - Plant Path., 57: 11251135.

Cortada L., Sorribas F.J., Ornat C., Andres M.F., VERDEJO-LUCAS S., 2009 - Response of tomato rootstocks carrying the $\mathrm{Mi}$-resistance gene to populations of Meloidogyne arenaria, M. incognita and M. javanica. Eur. J. Plant Path., 124: 337-343.

D'ERRICO G., CRESCENZI A., LANDI S., 2014 - First report of the southern root-knot nematode Meloidogyne incognita on the invasive weed Araujia sericifera in Italy. - Plant disease, 98: 1593.

D'Errico G., Giacometti R., Roversi P.F., Prasad L., Woo S.L., 2016 - Root knot disease caused by Meloidogyne incognita on tomato grown in soil-less culture in Italy. Redia, 99: 25-28. http://dx.doi.org/10.19263/REDIA99.16.04

D'Errico G., Marra R., Vinale F., Landi S., Roversi P.F., Woo S.L., 2017 - Nematicidal efficacy of new abamectin-based products used alone and in combination with indolebutyric acid against the Root-Knot Nematode Meloidogyne incognita. - Redia, 100: 95-101. http:// dx.doi.org/10.19263/REDIA-100.17.12

DROPKIN V.H., 1969 - The necrotic reaction of tomatoes and other hosts resistant to Meloidogyne: reversal by temperature. - Phytopath., 59: 1632-1637.
Garabedian S., VAn Gundy S.D., 1983 - Use of avermectins for the control of Meloidogyne incognita on tomatoes. - J. Nematol., 15: 503-510.

Gugino B.K., ABAwi G.S., Ludwig J.W., 2006 - Damage and management of Meloidogyne hapla using oxamyl on carrot in New York. - J. Nematol., 38: 483-490.

JaCQuet M., Bongiovanni M., Martinez M., Verschve P., Wajnberg E., CASTAGNone-Sereno P., 2005 -Variation in resistance to the root-knot nematode Meloidogyne incognita in tomato genotypes bearing the Mi gene. Plant Path., 54: 93-99.

Jarquin-Barberena H., Damasso A., De Guiran G., CARDIN M.C., 1991 - Acquired virulence in the plant parasitic nematode Meloidogyne incognita. 1 Biological analysis of the phenomenon. - Rev. Nématol., 14: 261-275.

Kaloshian I., Williamson V.M., Miyao G., Westerdahl B.B., 1996 - Resistance-breaking nematodes identified in California tomatoes. - Cal. Agricult., 50(6): 18-19.

LAMBERTI F., 1971 - Primi risultati di prove di lotta nematocida su tabacchi levantini in provincia di Lecce. - Il tabacco, 738: 5-10.

ManZanilla R.H., StarR J.L., 2009 -Interactions with other pathogens. In: Perry R.N., Moens M. \& Starr J.L. Eds, Root-Knot Nematode. Wallingford: CABI, pp. 223245.

Maynard D.N., Hochmuth G.J., Olson S.M., Vavrina C.S., Stall W.M., KuchareK T.A., 2003 - Tomato production in Florida. In: Olson S.M. \& Maynard D.N. Eds., Vegetable Production Guide for Florida, 2002-2003. Gainesville, FL: IFAS, University of Florida, pp. 259270 .

NyCZEPIR A.P., ThOMAs S.H., 2009 - Current and future management strategies in intensive crop production. In: Perry R.N., Moens M. \& Starr J.L. Eds., Root-knot Nematodes. Wallingford: CABI, pp. 412-443.

OKA Y., SHUKER S., TKACHI N., 2012 - Systemic nematicidal activity of fluensulfone against the root-knot nematode Meloidogyne incognita on pepper. - Pest Man. Sci., 68: 268-275.

Pullen M.B., Fortnum B.A., 1999 - Fosthiazate controls Meloidogyne arenaria and $\mathrm{M}$. incognita in flue-cured tobacco. - J. Nematol., 31(4S): 694-699. 
Putter I., Maconnel J.G., Preiser F.A., Haidri A.A., Ristich S.S., Dybas R.A., 1981 - Avermectins: novel insecticides, acaricides and nematicides from a soil microorganism. - Experientia, 37: 963-964.

Qiao K., LiU X., Wang H., Xia X., Ji X., WNaG K., 2012 Effect of abamectin on root-knot nematodes and tomato yield. - Pest Man. Sci., 68: 853-857.

RAGOZZINO A., D'ERRICO G., 2011 - Interactions between nematodes and fungi: a concise review. - Redia, 94: 123125.

RAVICHANDRA N.G., 2014 - Horticultural Nematology. Springer, India, pp. 412.

SAAD A.S.A., Massoud M.A., IBRAhIM H.S., Khalil M.S., 2011 - Management study for the root-knot nematodes, Meloidogyne incognita on tomatoes using fosthiazate and arbuscular mycorrhiza fungus. - J. Advanc. Agric. Res., 16: 137-147.

SAHEBANi N., HADAVI N., 2008 - Biological control of the root-knot nematode Meloidogyne javanica by
Trichoderma harzianum. - Soil Biol. Bioch., 40: 20162020.

Serges T., Colombo A., 2005 - L'innesto erbaceo della melanzana: effetti sul contenimento dei nematodi galligeni e della suberosità radicale. - Nematol. Medit., 33: 51-54.

Verdejo-Lucas S., Sorribas F.J., 2008 - Resistance response of the tomato rootstock SC 6301 to Meloidogyne javanica in a plastic house. - Eur. J. Plant Path., 121: 103107.

Verdejo-Lucas S., Cortada L., Sorribas F.J., Ornat C., 2009 - Selections of virulent populations of Meloidogyne javanica by repeated cultivation of $\mathrm{Mi}$ resistance gene tomato rootstocks under field conditions. - Plant Path., 58: 990-998.

Williamson V.M., RoBerTs P.A., 2009 - Mechanisms and genetics of resistance. In: Perry R.N., Moens M. \& Starr J.L. Eds., Root-Knot nematodes. Wallingford: CABI, pp. 301-325. 